\title{
Plant offerings from the classical necropolis of Limenas, Thasos, northern Greece
}

\author{
F. Mégaloudi ${ }^{1}$, S. Papadopoulos ${ }^{2} \&$ M. Sgourou $\dagger$
}

Funeral pyres identified at a fourth-century $B C$ cemetery on Thasos have produced a range of plants. The authors show that strongly represented among them are pomegranate, garlic and grape, as well as bread - foodstuffs for funeral feasts and with significance for religious practice.

Keywords: Greece, fourth century BC, necropolis, cemetery, mortuary practice, cist graves, plants, pomegranate, grape, garlic, bread

\section{Introduction}

The ancient city of Thasos (also known as Limenas), situated on the north edge of the island of Thasos, was an important site of the Greek world (Figure 1). Limenas was colonised by the people of Paros at the beginning of the seventh century BC, following a prophecy from the oracle at Delphi obtained by their leader Telesicles. The city they constructed had a harbour and developed as an important naval centre. In the fifth century BC the acropolis and urban area, including the parliament, a prytaneum, a market, a theatre, a conservatory, sanctuaries and several public buildings were enclosed by a wall $c .4 \mathrm{~km}$ long, part of which survives. Research on the site has been a long-standing project of the Ecole Française d'Athènes, which initiated excavations in the early twentieth century; excavations continue today in collaboration with the Archaeological Unit of Kavala.

Archaeological investigation of the necropolis started in the $1970 \mathrm{~s}$ as a part of a rescue excavation programme of the Archaeological Unit of Kavala. The largest portion of the cemetery has been contacted under two separate farms, the farm of Soultos and the farm of Chryssogelos. Both have yielded important archaeobotanical remains, some of which derive from pyres within cemeteries and form the subject of this paper.

\section{Context: cemeteries and pyres}

The first archaeological investigation at the Soultos farm site revealed 54 cist graves (Archaiologikon Deltion 29 1973-1974 B2: 788; 301975 B: 278; 371982 [1989] B2: 316-22). In 1996 the investigation of the graves located at the north of the enclosure was

1 School of Social and Cultural Studies, Faculty of Arts, Humanities and Social Sciences, University of Western Australia - Perth, 65 Stirling Highway, 6009 WA, Australia (Email: fmegaloudi@yahoo.fr)

$218^{\text {sb }}$ Eforeia of Prebistoric and Classical Antiquities, Erythrou Stavrou 17, 65110 Kavala, Greece (Email: strapapa@in.gr)

$\dagger$ This article is dedicated to the memory of the late Dr Marina Sgourou whose untimely passing sadly interrupted her important work on Thasos island.

Received: 12 December 2005; Accepted: 26 May 2006; Revised: 15 September 2006

ANTIQUITY 81 (2007): 933-943 
completed by $\operatorname{Dr} M$. Sgourou. A burnt deposit, or pyre, (pyra $\mathrm{B}$ ) was discovered among the graves, although it was not directly related to a tomb (Figure 2). The deposit was associated with an assemblage of cooking pots (kuathia and lopadia) dated to the end of the fourth century BC. No animal remains were recovered from this pyre.

The Chryssogelos farm site (Figure 3) is located near the sea, at the Molos area, around $1.5 \mathrm{~km}$ west of the modern harbour of Limenas. Seventeen burials have been excavated here: nine cist graves, two tile graves, five stone sarcophagi and one jar burial in amphora. All the graves had the same orientation (northwest-northeast). Small pottery vases and small iron objects were placed in the majority of the graves. According to the evidence currently

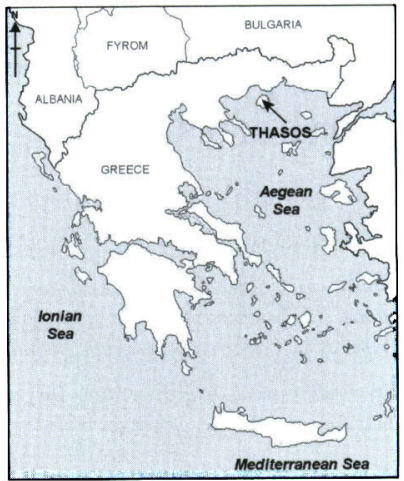

Figure 1. The location of Thasos, Greece. collected, it seems that this part of the cemetery belongs to two chronological periods: the majority of the cist graves and the jar burial are dated to the fourth century BC, while the tile graves and the sarcophagi are dated after the second century BC.

A pyre (enaghismos) was related to the cist grave No. 12, containing the remains of a young child (Figure 4). The charred plant assemblage was associated with burnt cooking pots, a silver bag and numerous small statues that allowed the finds to be dated to the second half of the fourth century BC. A small quantity of animal bones, probably of goat and sheep, was discovered in the grave, but no further analysis was performed on the archaeozoological material. Three different burial practices have been observed among the 65 burials excavated so far: cremation, inhumation and jar burial (Aggelarakis 1998).

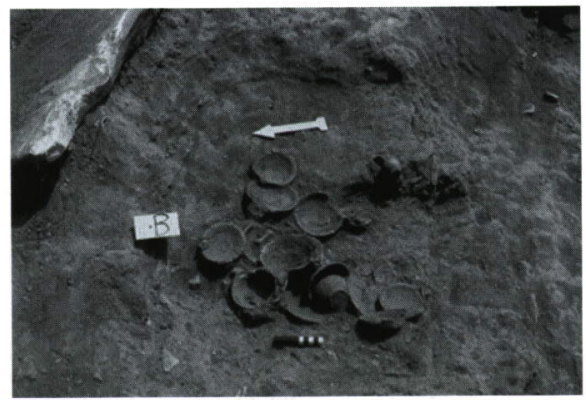

Figure 2. The pyre $B$ in Soultos farm. 


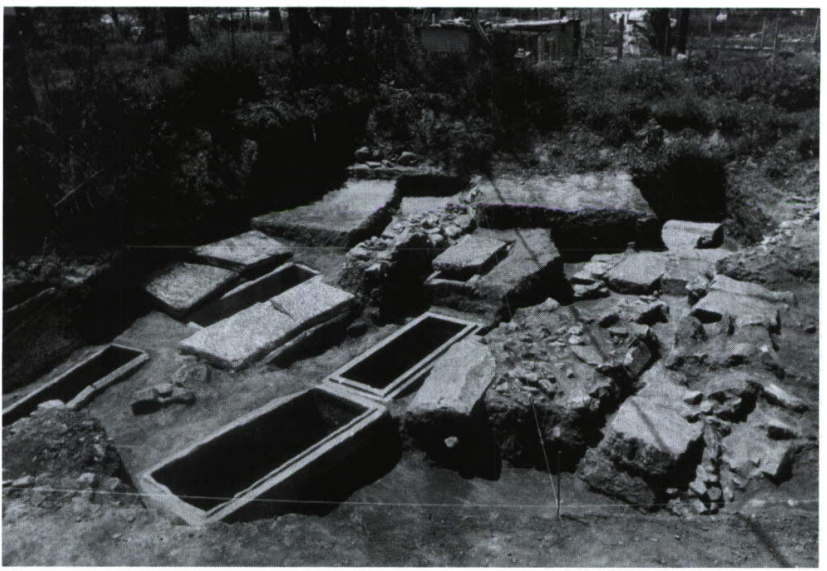

Figure 3. General view of Chryssogelos farm.

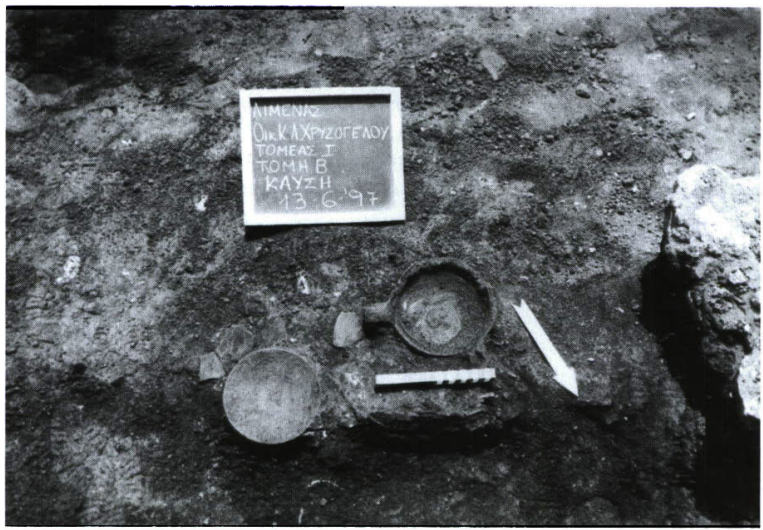

Figure 4. The pyre of Chryssogelos farm.

\section{The plant remains from the pyres}

The botanical remains were collected from the pyres where they were observed with the naked eye. All samples were processed and studied by one of the authors (F. Megaloudi) 
Table 1. Charred plant remains from the pyres of Soultos and Chryssogelos farms.

\begin{tabular}{|c|c|c|c|}
\hline \multicolumn{2}{|c|}{$4^{\text {th }}$ century BC Necropolis of Limenas-Thasos } & \multirow{2}{*}{$\begin{array}{c}\begin{array}{c}\text { Pyra B } \\
\text { Soultos }\end{array} \\
2 \mathrm{fg}\end{array}$} & \multirow[t]{2}{*}{$\begin{array}{c}\text { Pyra 11 } \\
\text { Chryssogelos }\end{array}$} \\
\hline Juglans regia & Walnuts & & \\
\hline Olea europaea var. sativa & Olive stones & $1 \mathrm{fg}$ & \\
\hline Malva sp. & & 1 & \\
\hline Fabaceae & & 2 & \\
\hline Bread remains & & $*$ & * \\
\hline Allium sativum & Garlic & & 18 cloves $+37 \mathrm{fg}$ \\
\hline Triticum aestivum/durum & Free-threshing wheat & & 1 \\
\hline Punica granatum & Pomegranate & & 3 \\
\hline Vitis vinifera & Grape & & $10+1 \mathrm{fg}$ \\
\hline $\begin{array}{l}\mathrm{fg}=\text { fragment } \\
*=\text { present }\end{array}$ & & & \\
\hline
\end{tabular}

using manual flotation. Floated material was collected by a set of two sieves with apertures of $1 \mathrm{~mm}$ and $0.3 \mathrm{~mm}$ each. Processing of the samples took place at the Museum of Thasos. The flots collected were subsequently examined in order to determine the richness of the samples. Flots were examined by comparison with modern reference material in the Wiener Laboratory of the American School of Classical Studies at Athens while heavy residues were examined at the Thasos Museum.

The inventory of plants identified is presented in Table 1. The main species recorded are pomegranate seeds (Punica granatum), garlic (Allium sativum), grape vine (Vitis vinifera) and fragments of charred bread. These remains seem to have a symbolic meaning, which should explain their presence in a funeral context (see also Mégaloudi 2004; 2005a; 2005b).

Pomegranate (Punica granatum L.) is a deciduous bush or small tree, highly valued in traditional Mediterranean horticulture. Its fruits contain numerous seeds and are covered with a juicy flesh which can be eaten fresh, or whose juice can be extracted. Punica granatum can be used in medicine both for its own perceived curative qualities and for its use as an ingredient for medicinal recipes (Fournier 1948). The bark of the pomegranate tree may be used as a very strong purgative, although several side effects are reported (Leclerc 1925). The pericarp of the fruit can also be used for dying giving a natural lemon-yellow or reddishbrown colour (Polunin 1980). The Greek name for pomegranate is Roia or Roa. Some scholars (André 1956) believe that this word derives from the verb Réo (flow) that indicates the astringent properties of the fruit in ancient medicine (Dioscorides $M M$ I.110; Pliny HN 23.106). In Latin the fruit was known either as malum punicum or malum granatum (André 1985). The adjective punicus refers to Carthage, a Phoenician colony in northern Africa that according to Pliny $(H N 13.112)$ is the origin of the species. However, the wild ancestor of the cultivated pomegranate is well defined: wild forms of Punica granatum grow in the south Caspian belt, in north-eastern Turkey and in Albania and south Serbia and the domestication of the species by clonal propagation brought about an increase in fruit size (Zohary \& Hopf 2000). Pomegranates probably reached the western Mediterranean and the north-western parts of Africa from Cyprus through the Phoenicians (Jacomet et al. 
2002). Pomegranate seeds are found in Mycenaean deposits at Tirynth (Kroll 1982). From here, the fruit came to Italy where it is recorded in excavated assemblages in sixth and fifth centuries (Ciaraldi 1999, cited in Jacomet et al. 2002).

Punica granatum is not a common find in archacological assemblages in Europe (for a review of pomegranate findings in northern Europe and Italy see Jacomet et al. 2002: 85). In Greece - with the exception of the finds at Tirynth that represent domestic areas pomegranate seeds are mainly related to ritual deposits (Luce et al. in press; Kučan 1995; Bookidis et al. 1999). Pomegranates had a particular importance for the dead, and clay replicas have been found in the cemetery at Eleusis dating from the Geometric Period (Farnell 1896-1909). The fruits were a symbol of blood and death but also of fertility as their appearance when split open, with many chambers containing dark red seeds, is similar to the way in which the Greeks visualised the female womb (King 1996). The pomegranate was venerated in the cult of Hera, mother of Gods, protector of marriage and childbirth (Baumann 1993). According to Pausanias (Descr. Gr 2.19.3), there existed at the Sanctuary of Hera at Argos a chryselephantine statue of the goddess holding a pomegranate in her hand. The species was also sacred to both Aphrodite and to Athena. In Greek mythology pomegranate is related to the abduction of Persephone. Persephone was condemned to remain beneath the earth for half of the year because by eating a pomegranate in the Underworld she had involuntarily married Hades (Homer Hymn to Demeter. 372, 412). The Archaic korai were also often depicted holding a pomegranate in one hand, and this is probably where their connection to Persephone originates. Pomegranate was thought to have healing properties for fever after childbirth and Hippocrates administers a mixture of pomegranate juice mixed with lentil flour, then cooked with cumin, salt, oil and vinegar, that has to be given to the patient when cold (Diseases of women: I.75). Pomegranates may operate in that case at a symbolic level, their many seeds promoting fertility (King 1996). This symbolic meaning of the fruit can be seen in another recipe designated to promote conception that consists of pomegranate juice mixed with the milk of a woman suckling a male child.

There were 18 whole cloves of garlic ranging from $15 \mathrm{~mm}$ to $19 \mathrm{~mm}$ in length (Figure 5). The dimensions of the cloves suggest that the remains recovered probably belong to the cultivated variety Allium sativum L. Garlic is a perennial plant used widely as a culinary herb. The wild ancestry of garlic is not definitely established. Allium longicuspis a species native of Central Asia is the most probable candidate for the ancestor of the cultivated variety (Zohary \& Hopf 2000). According to Herodotus (Histories II.125),

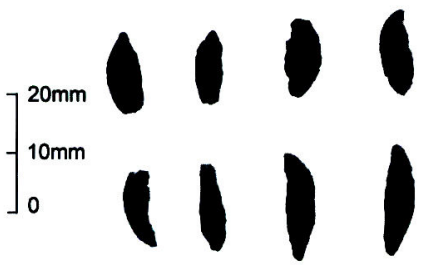

Figure 5. Garlic remains from the necropolis of Limenas. garlic figured among the food provisions given to the workers that built the pyramid of Cheops, but this information has been doubted (Manniche 1999). We know from Theophrastus (HP 7.4.11) that, at the end of fourth century BC, garlic, skórodon, was propagated from seed or from planting of individual cloves. He describes a plant named móly that grows on Mount Kyllene and has a 'round root like an onion and a 
leaf like squill' (HP 9.15.7). According to Theophrastus, this plant is the moly mentioned by Homer and is used 'against spells and magic arts' (HP 9.15.7). In Homer's Odyssey, móly is the antidote that Hermes gives to Ulysses to protect him from the spells of Circe; Homer describes the plant as being black at the root but its flower was like milk' (Odyssey 302-6). This raises the question as to whether the Homeric moly and the móly of Theophrastus is the cultivated garlic and if so, if garlic was cultivated since Homeric times. Amigues (1995), in her comparative study of the plants called móly mentioned in ancient texts, concluded that the Homeric móly and the móly of Theophrastus are both Allium sativum L. In which case, we could assume that garlic was a constituent of ancient vegetable gardens at least since Homeric times. Dioscorides (in Pliny, Natural History II.152) reports an Egyptian variety of undivided garlic used by sorcerers and magicians (Meeks 1993). In classical Greece, the plant was appreciated both as a magical plant and a garnishing herb. According to Theophrastus (HP 7.4.11), garlic was the principal ingredient for mittotós, a kind of sauce similar to modern skordaliá. In Aristophanes' Acharnians garlic enrages those who ate it (Acharnians: 166) and in Thesmophoriazousae an adulterous wife chews garlic before her husband returns home, so she can avoid kisses (Th. 494-96). Medicinally, garlic seems to have been something of a panacea. Hippocrates, Dioscoride and Galen recommended it, and Pliny (NH X.50-57) notes its healing properties as an antiseptic (applied to caries or used as a remedy against lung infections). The species contains a highly antiseptic substance, allicin, that is produced when garlic is crushed or chewed (Fournier 1948; Couplan 1983). This is the reason why the plant has various applications in medicine (Fournier 1948).

Garlic was closely related to the cult of Hecate, a chthonian divinity and patron of sorcerers (Theocritus Idylls II). In Theophrastus Characters (XVI), garlic was placed on the piles of stones at crossroads, as a supper for Hecate; Superstitious (XVI) purifies himself if he crosses anyone feasting on garlic. Hecate was the symbol of every occult power (pathogenic microbes were thought to be 'bad spirits'). Garlic, a highly antiseptic plant, was believed to protect against bad spirits and consequently against microbes. This belief has survived in eastern Europe, where garlic cloves suspended on windows, are supposed to keep vampires out of houses (Collectif 1964). Similar beliefs about garlic have survived in modern Greek everyday life. For example when an adult sets eyes on a baby (vulnerable creature), he or she symbolically spits and says 'skórda' (the Greek word for garlic cloves), or when someone receives a compliment he should say 'garlic into your eyes'; both uses of the word aim to expel evil (see also Mégaloudi 2005a).

The remains of grape, Vitis vinifera, from the necropolis of Thasos had preserved part of the pericarp that was visible as an amorphous black mass surrounding the seed (Figure 6). This leads us to suggest that whole fresh fruits were thrown into the sacrificial fire. Charring experiments carried out with grape vines have shown differential carbonisation of fresh and dried fruit (Margaritis \& Jones 2006). While dried raisins are shrivelled and swollen after being charred, it is not the same for fresh grapes. The soft and juicy parts of the fruit boil away, leaving a black mass surrounding the seed (Margaritis \& Jones 2006). If these finds represent whole fresh grapes, this would suggest that the burial took place in the early autumn, since that is when the grapes would have been harvested; but according to Pliny $(N H 14.3 .16,18)$ grapes can last throughout the 


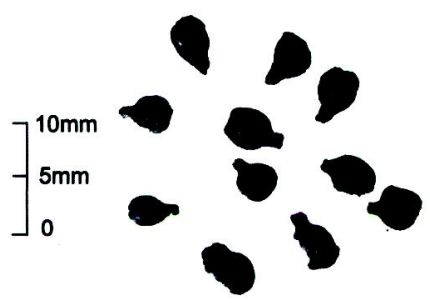

Figure 6. Grape remains from the necropolis of Limenas.

winter if hung from the ceiling and others are preserved in their own juice in sealed jars or in must. Whole grapes are not a common discovery in Greece; the only archaeological occurrence of whole grapes so far comes from a burnt offering at Messene in the Peloponnese (Mégaloudi 2005b) and from the ninth/sixth century BC cemetery of Orthi Petra at Eleftherna in Crete (Mégaloudi unpublished). However whole carbonised grapes are relatively often found as grave goods in other parts of Europe, for example in Roman cremation graves in Switzerland (e.g. Petrucci-Bavaud 1996).

Wine played an important role in the ritual of death and wine was often used to quench the remains of the funeral pyre and as an offering to the dead. This ancient custom survives today in the island of Thasos, where it is common for the priest to pour red wine onto the body of the deceased prior to final interment. Once the body is buried, the wine pitcher used to anoint the corpse is smashed (personal observation).

The offerings from the necropolis of Thasos contained numerous fragments of

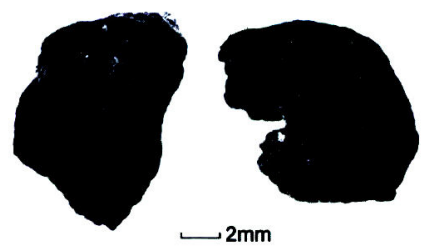

Figure 7. Charred bread remains from the necropolis of Limenas. what seems to have been charred bread. The fragments are small (with a maximum length of $14 \mathrm{~mm}$ ) but they represent the first evidence of charred bread recorded in Greek funerary contexts (Figure 7). Information on different kinds of Greek breads and cakes can be found in ancient literary sources (e.g. the Hippocratic Corpus discusses the medicinal uses of bread and Athenaeus Deipnosophistae lists several types of bread) and in votive offerings, mainly those discovered in the Sanctuary of Demeter and Kore at Corinth dating to the fifth century BC (Brumfield 1997; Bookidis et al. 1999). Among these votive offerings can be identified seven different flat cakes with round spherical or oblong shape. Literary sources indicate that sacrificial bread and cakes had various forms according to the deity being honoured, including animal shapes (goats, deer etc.) and some even in the image of a woman's breast (Curtis 2001). Aristophanes in Lysistrates (v.601) mentions a honey cake called melitoutta that was given to the dead in order to ward off Kerberos (Cerberus). These cakes may be represented on funeral vessels (lekythoz) as small round objects projecting from the baskets that celebrants carried to the tomb (Garland 1985).

\section{Discussion}

In the Roman world, funerary plant offerings are a frequent find (e.g. Marinval 1993; Kreuz 1995; Petrucci-Bavaud \& Jacomet 1997; Castiglioni et al. 1999; Bakels \& Jacomet 2003; 
Bouby \& Marinval 2004; Mégaloudi 2004). By contrast data on plant offerings from funeral contexts in Greece are still scarce (Mégaloudi 2004). Although plant remains seemed to have played an important role in sacrificial/funeral offerings, the material of such context is rarely studied and published (Mégaloudi 2006); many excavators do not apply any technique for the collection of bio-archaeological remains, assuming, wrongly, that all the information can be found in literary sources, stone architecture or in the various artefacts.

Carbonised remains of figs and grapes have been reported from the Geometric cemetery of Tsikalario on the island of Naxos (Daux 1968), from a burial context dated to the fifth century BC at Akraiphia in Boeotia (Andreiomenou 1994). Remains of walnuts, pine nuts and grape vine are identified in funeral pyres from the Matzourani farm at the necropolis of Limenas (Thasos) dated to the fifth and fourth centuries BC (Mégaloudi unpublished) while plant funeral offerings (cereals, almonds, olives, figs and grape vine) in Greek contexts are found in the necropolis of Salamina (Cellarka) in Cyprus (Karageorghis 1966: 368-82) as well as in a Greek tomb in the Crimea region (Ukraine) dated to fourth century BC (Wasylikowa et al. 1991). These remains consist of pears, almonds, vine and chestnuts. Plant remains were recovered from the tombs at the Early Iron Age Cemetery at Torone (Gyulai \& Kelertas in Papadopoulos 2005). The charred seeds consisted of domestic species such as pulses (lentils, bitter vetch and broad bean), fruits (blackthorn and grape) and barley and probably represent grave goods.

Funeral plant offerings are reported from the sixth-century deposits of the cemetery at Orthi Petra in Eleftherna at Rethymno, Crete. The remains consist of fig fruits, stone pine nuts, olives and whole grapes that were thrown intact in the sacrificial fire as a part of a grave offering (Mégaloudi unpublished). The aforementioned burnt deposits clearly indicate that plant food offerings were made at the grave but little attention has been given so far to the study of such remains.

\section{Feeding the Dead?}

In the Homeric epics the deceased must receive the proper funerary rites before the spirit may cross to Hades, otherwise it is obliged to wander over the earth (Iliad 23.71; Odyssey 11.72). The funeral was comprised of three parts, the laying out of the body (prothesis), its conveyance to the place of interment (ekfora) and the deposition of the cremated or inhumed remains (for a detailed description of Greek burial customs the reader is referred to Kurtz \& Boardman 1971; Garland 1985; Sourvinou-Inwood 1996). Food offerings were an integral part of burial rituals and the only category of dead that did not receive such honours were suicides (Artemidoros Oneirkrotika 14 T). However, little is known about what food was served to the dead and about how it was prepared. Literary sources allude to the importance of the funeral meal but do not describe it. In general they imply that the funeral meal was taken at the house of the dead and it was an occasion for relatives to gather and speak of the dead person. This was the perideipnon, the banquet shared by the relatives in the dead man's house immediately after the ekfora at which, according to Artemidoros (5.82.T) the dead himself was believed to be present.

The meals prepared at the tomb were known as trita and enata, the third and ninth day rites (Garland 1985). The trita took place on the same day as the burial, perhaps soon 
after the perideipnon. On the ninth day after the burial the relatives gathered at the tomb to perform the enata. The exact composition of those meals is not known but probably they did not differ from those performed at the graveside at other times during the year. On the thirtieth day after death the rite known as triakostia was performed. It seems to have been customary to deposit sweepings (kallysmata) from the house on the grave when performing this rite that, at least in Athens, marked the final stage in the obsequies (Garland 1985).

It has been emphasised that there are only minor differences between food plants of dead and living people (Marinval 1993; Kreuz 1995; Petrucci-Bavaud \& Jacomet 1997; Bakels \& Jacomet 2003; Bouby \& Marinval 2004). The Limenas finds comprised edible species that one would expect to find in every household kitchen at that time (Table 1), although some species, such as garlic or pomegranate, seem to have had a symbolic meaning. It is extremely difficult to say whether the ritual meals at Limenas were an offering to the dead or the remains of funerary meals consumed by those present at the burial rite. It has been stated that the living did not participate in the meals that were served to the dead, as table-fellowship with the deceased was considered unlucky (Farnell 1921). According to Pausanias (Description of Greece 2.10.1) the food sacrifice consecrated to Hercules at Sykion was considered taboo for use by the living. However, this could have prevailed in the case of heroes and maybe it was not the same in the case of the ordinary dead. On the other hand, the Will of Epiktete permitted relatives gathered in the shrine to participate in the sacrificial feast of the dead but separate portions were assigned to each group.

The existing evidence does not allow us to determine which funerary rite was celebrated at the time of the plant offering and the only assumption that may be made is that the funeral took place in early autumn, as the presence of pomegranates and grapes might indicate. It is interesting to note that triakostia (the thirtieth day after death) was associated with the worship of Hecate. Garlic, a species that dominates the burnt deposits, was related to the cult of Hecate and one could assume that the rite taking place at the tomb was that of triakostia. However it is not possible to say if that ritual took place on the thirtieth day after the death/or burial, since the word triakostia was also the name for a ritual performed each month, either on the thirtieth day or on the day of death of the deceased (Garland 1985).

The plant offerings from both cemeteries are related to cist graves containing inhumations. In the first case (Soultos farm) the offering was not related to a specific grave. No burnt offerings were discovered related to other grave types (e.g. jar burials or tile graves). This raises the question as to whether a specific pattern existed at the cemetery of Limenas, according to which plant offerings were related to a particular grave, burial type or individual (i.e. a cist grave with inhumation). The limited number of pyres does not allow such a hypothesis. The absence of burnt offerings from the other graves of the cemetery is more likely to be a reflection of taphonomic bias and/or insufficient recovery techniques, rather than a specific pattern of distribution of plant offerings. Archaeobotanical data from funeral contexts in Greece are still scanty (see above) and in most cases no information is provided on the location of these remains. Thus, it is not possible to address a pattern of spatial distribution of burnt offerings discovered in funeral contexts and to compare it with the Limenas finds. 
Advance in this type of research will depend on the collection of new information from funeral contexts, with large scale sampling, spatial analysis of the finds and fine sieving, in order to produce a homogenous archaeobotanical record of burnt plant offerings.

\section{Acknowledgements}

We are very grateful to Dr Sherry Fox, Director of the Wiener Laboratory of the American School of Classical for her valuable comments and improvements on an earlier draft of this paper. All shortcomings remain our own.

\section{References}

Aggelarakis, A. 1998. Physical Anthropology and Palaeopathology at the Classical Necropolis of Thasos, AEMTH: 780-89.

Amigues, S. 1995. Des plantes nommées Moly. Journal des Savants janvier-juin 1995: 3-29.

ANDRÉ, J. 1956. Recherches érymologiques sur certains noms de plantes latins. Latomus, 15 (1): 302-03

-1985. Les noms de plantes dans la Rome antique. Paris: Les Belles Lettres.

Andreiomenou, A.K. 1994. La nécropole d'Akraiphia, in Nécropoles et societtés antiques (Grèce, Italie, Languedoc): 99-126. Naples: Cahiers du Centre Jean Berard.

Aristophanes (trans. J. Henderson) 1998. Acharnians. Knights Loeb Classical Library.

-(trans. J. Henderson) 2000. Birds. Lysistrata. Women at the Thesmophoria. Loeb Classical Library.

Artemidoros (trans. R.J. White) 1975. The interpretation of Dreams: Oneirocritika. Park Ridge (NJ): Noyes.

Bakels, C. \& S. Jacomet. 2003. Access to luxury foods in Central Europe during the Roman period: the archaeobotanical evidence, in $M$. van der Veen (ed.) Luxury foods. World Archaeology 34 (3): 543-57.

Baumann, H. 1993. Greek Wild Flowers and Plant Lore in ancient Greece. London: The Herbert Press.

Bookidis N., J. Hansen, L. Snyder \& P. Goldberg. 1999. Dining in the sanctuary of Demeter and Coré at Corinth. Hesperia 68: 1-54.

Bouby, L. \& P. Marinval. 2004. Fruits and seeds from Roman cremations in Limagne (Massif Central) and spatial variability of plant offerings in France. Journal of Archaeological Science 31: 77-86.

Brumfield, A. 1997. Cakes in the Liknon: Votives from the sanctuary of Demeter and Core on Acrocorinth. Hesperia 66.

Castiglioni, E., M. Cotrini \& M. Rotroli. 1999. Mariano, Via T. Grossi: analisi archeobotaniche, in G. Frigerio (ed.) Storia di Mariano Comense. dalla preistoria all'alto medioevo 1: 107-12. Mariano Comense: Società Archeologica Comense.
Collectir. 1964. Encyclopédie du Monde Végétal. Paris: Quillet.

Couplan, F. 1983. Le régal végttal. Plantes sauvages comestibles (Encyclopédie des plantes comestibles de l'Europe vol. 1). Paris: Debard.

Curtis, R. 2001. Ancient Food Technology. Technology and Change in History vol. 5. Leiden: Brill.

Dioscorides (trans. T.A. Osbaldeston) 2000. De materia medica. Johannesburg, South Africa: IBIDIS Press.

Daux, G. 1968. Chronique des fouilles 1967. Bulletin de correspondance bellenique 92: 954-59.

FARNeLL, L.R. 1896-1909. The Cults of the Greek States. 5 vols. Oxford: Clarendon Press.

-1921. Greek Hero Cults and Ideas of Immortality. Oxford: Clarendon Press.

Fournier, P. 1948. Le livre des plantes médicales et vénéneuses de France, 1, 2 \& 3. Paris: P. Lechevalier.

GarLand, R. 1985. The Greek Way of Death. London: Duckworth.

Hippocrates, (trans. E. Hanson) 1975. Diseases of women I. Chicago: University of Chicago Press.

Herodotus (trans. A.D. Godley) 1920. Histories. vol. II. Loeb Classical Library.

Homgr (trans. A.T. Murray, revised by G.E. Dimock) 1919. Odyssey. vol. 1-2. Loeb Classical Library.

-(trans. A.T. Murray) 1924-25. Iliad. vol. 1-2. Locb Classical Library.

-(trans. M.L. West) 2003. Homeric Hymns. Loeb Classical Library.

Jacomet, S., D. Kucan, A. Ritter, G. Suter \& A. Hagendorn. 2002. Punica granatum (pomegranates) from early Roman contexts in Vindonissa (Switzerland). Vegetation History and Archaeobotany 11: 79-92.

Karageorghis, V. 1966. Chronique des fouilles a Chypre en 1965. Bulletin de correspondance bellenique 80: 363-82.

KING, H. 1996. Food and Blood in Hippocratic Gynaecology, in J. Wilkins, D. Harvey \& M. Dobson (ed.) Food in Antiquity: 12-24. Exeter: Exeter University Press. 


\section{F. Mégaloudi, S. Papadopoulos \&. M. Sgourou}

KrEUZ, A. 1995. Funkrionale und konzeptionelle archäobotanische Daten aus römerzeitlichen Brandbestattungen. Berichte der Kommission fur Archdologische Landesforschung in Hessen 3: 93-97.

KroLl, H. 1982. Kulturpflanzen von Tiryns. Archäologischer Anzeiger 1982: 467-85.

Kurtz, D. \& J. Boardman. 1971. Greek Burial Customs. Ithaca (NY): Cornell University Press.

Kư̌an, D. 1995. Zur Ernährung und dem Gebrauch von Pflanzen im Heraion von Samos im 7. Jahrhundert v. Chr. Jahrbuch des Deutschen Archäologischen Instituts, Band 110: 1-64.

LeClerc, H. 1925. Les fruits de France. Paris: Masson.

Luce, J.-M., P. Marunval, J. Renault-Miskovsky \& S. Thiebaut. In press. Fouilles de Delphes, Tome II: Topographie et architecture, a la frontière du profane et du sacre. Athens: Ecole Française d'Athènes.

Manniche, L. 1999. An Ancient Egyptian Herbal (first edition 1989). London: British Museum Press.

Margarttis, E. \& M. Jones. 2006. Beyond cereals: crop processing and Vitis vinifera L.: ethnography, experiment and charred grape remains from Hellenistic Greece. Journal of Archaeological Science 33(6): 784-805.

Marinval, P. 1993. Etudes carpologiques d'offrandes alimentaires végétales dans les sépultures gallo-romaines: réflexions préliminaries, in A. Ferdière (ed.) Monde des morts, monde des vivants en Gaule rurale: 45-65. Tours: Actes du colloque ARCHEA/AGER, $\sigma^{c}$ supplément à la Revue Archeologique du Centre de la France.

MeEks, D. 1993. Oléculture et viticulture dans l'Egypte pharaonique, in M.-C. Amouretti \& J.-P. Brun (ed.) La production du vin et de l'huile en Méditerranée (Bulletin de correspondance hellénique, supplément 26): 3-38.

MEgaloudi, F., 2004. Funeral plant offerings from historical sites: a preliminary study, in L. Smejda \& J. Turek (ed.) Spatial analysis of funerary areas: 109-14. Plzen: University of West Bohemia.

-2005 a. Wild and Cultivated Vegetables, Herbs and Spices in Antiquity (900-400 BC). Environmental Archaeology 10.1: 71-80. -2005b. Burnt sacrificial offerings at Hellenistic Times: An archaeobotanical case study from Messene, Peloponnese, Greece. Vegetation History and Archaeobotany 14: 329-40.

-2006. Plants and Diet in Greece from Neolithic to Classic Period: the archaeobotanical remains (British Archaeological Reports International Series 1516). Oxford: Archaeopress.

Papadopoulos, J.K. 2005. The Early Iron Age Cemetery at Torone (Monumenta Archaeologica 24). Los Angeles (CA): Cotsen Institute of Archaeology at UCLA.

Pausanias (trans. W.H.S. Jones, arranged by R.E. Wyeherley) 1935. Description of Greece, vol. 4. Loeb Classical Library.

Petrucci-Bavaud, M. 1996. Pflanzliche Speisebeigaben in den Brandgräbern, in C. Haeffele (ed.) Die römische Gräber an der Rheinstrasse 46 des Nordwestgräberfeldes von Augusta Raurica. Jahresberichte aus Augst und Kaiseraugst 17: 253-59.

Petrucci-Bavaud, M. \& S. Jacomet. 1997. Zur Interpretation von Nahrungsbeigaben in römischen Brandgräbern. Ethnographisch-Archäologische Zeitschrift 38: 3-4, 567-93.

PuINY (trans. H. Rackham) 1967. Natural History III, Books VIII-XI. Loeb Classical Library.

Polunin, O. 1980. Flowers of Greece and the Balkans. Oxford: Oxford University Press.

Sourvinou-INwoon, CH. 1996. Reading Greek Death: to the end of the Classical Period. Oxford: Clarendon Press.

Theophrastus (trans. J. Rusten) 2003. Characters. Loeb Classical Library.

-(trans. Sir Arthur Hort) 1916. Enquiry into Plants, 2 vol. Loeb Classical Library.

Wasylikowa, K., M. Carciumaru, E. Hajnalova, B.-P. Hartyany, G.A. Pashkevich \& Z.V. YANUSHEvich. 1991. East-Central Europe, in W. van Zeist, K. Wasylikova \& K.-H. Behre. (ed.) Progress in OLd World Palaeoethnobotany: 207-39. Rotterdam: Balkema.

Zohary, D. \& M. Hopr. 2000. Domestication of Plants in the Old World. Oxford: Clarendon Press. 